\title{
EFFECT OF COMPOST AND SOME STIMULTORY SUBSTANCES ON GLADIOLUS PLANT B. CORMS AND CORMELS PRODUCTIVITY AND CHEMICAL COMPOSITION
}

\author{
M.A.H. Abdou, M.K. Aly, A.A. El-Sayed, A.R. Khalil and T.A. Helmy \\ Horticulture Department, Faculty of Agriculture, Minia University, Egypt
}

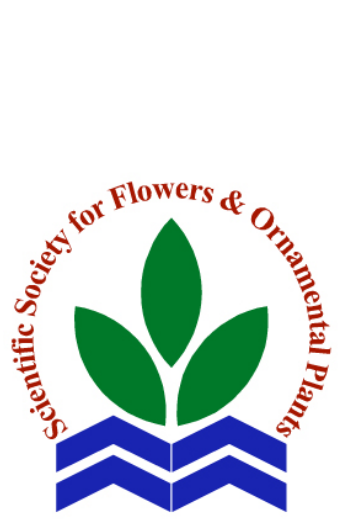

ABSTRACT: A field experiment was conducted during the two successive seasons of 2017/2018 and 2018/2019 in the Nursery and Laboratory of Ornamental Plants, Faculty of Agriculture, Minia University to study the effect of compost $(7.5,10.0$ and 12.5 ton/fed) and seven treatments of stimulatory substances i.e. control, seaweeds extract $(300 \mathrm{ppm})$, amino acids $(200 \mathrm{ppm})$, ascorbic acid (100 ppm), salicylic acid $(50 \mathrm{ppm})$, active yeast $(5 \mathrm{~g} / \mathrm{l})$ and Minia azotein (50 $\mathrm{ml} /$ plant), as well as, their interaction on corms and cormels productivity of gladiolus and some chemical composition constituents. The obtained results indicated that the three levels of compost significantly increased corm diameter, number of cormels/plant, fresh Scientific J. Flowers \& weights/plant, as well as, chemical composition (photosynthetic Ornamental Plants, pigments and N, P and $\mathrm{K} \%$ ) as compared to control. The maximum 8(1):75-86 (2021). values were obtained by using compost at 12.5 ton/fed. Treated plants

Received:

$3 / 12 / 2020$

Accepted:

$25 / 12 / 2020$

Corresponding author: M.A.H. Abdou mahmoud.abdo@mu.edu.eg with any of six used stimulatory treatments considerably increased corm and cormels productivity and chlorophyll $\mathrm{a}, \mathrm{b}$ and carotenoids content, as well as, the percentage of N, P and K in the leaves. Minia azotein was the most effective than the other treatments in this concern the interaction treatments were obtained due to fertilizing gladiolus with compost at $12.5 \mathrm{ton} / \mathrm{fed}$ and inoculation of the soil with either Minia azotein or with the sprayed plants with active yeast.

Key words: Gladiolus, compost, seaweeds extract, amino acids, ascorbic, salicylic, yeast and Minia azotein.

\section{INTRODUCTION}

Gladiolus grandiflorus cv. Eurovision has some important characters such as its favorable height $(120$ to $130 \mathrm{~cm})$, sturdiness of stem is good with large florets size which are showy rose florets $(7.5$ to $8.5 \mathrm{~cm})$. Besides, it can be bloomed in winter to early spring. The possibility of exporting of its flowers could be increased (Ahmed, 2013).

Corm and cormel traits i.e. corm diameter, fresh and dry weights of corm, cormels number, fresh and dry weights/cormel and number of contractile root per corm, as well as, the three photosynthetic pigments (chlorophyll a, b and carotenoids contents) and of $\mathrm{N}, \mathrm{P}$ and $\mathrm{K}$ $\%$ in the leaves and corms were increased due to fertilizing gladiolus plants with compost reported by Ruppenthal and Castro (2005), Chandar et al. (2012), Ahmed (2013), Abdou and Ibrahim (2015), Hassan (2016), Tirkey et al. (2017), Baruati et al. (2018); Beck et al. (2019), Karagöz et al. (2019) and Hassan and Abd El-Azeim (2020).

The impact of stimulatory substances on enhancing corms and cormels production, as well as, the photosynthetic pigments and some nutrients (N, P and $\mathrm{K} \%$ ) of gladiolus 
plant was emphasized by Hassan (2016) on gladiolus plants regarding seaweeds extract; Abd El-Aziz et al. (2009), Sewedan et al. (2012) and Hashish et al. (2015), Hassan (2016) and Khattab et al. (2016) on gladiolus plants concerning amino acids; furthermore, Abd El-Aziz et al. (2009), Abo Leila and Eid (2011), Abdou and Ibrahim (2015), Khalil (2015), Ahmed (2019) and Abdou et al. (2019), on gladiolus, showed that all corm and cormels productivity were increased with ascorbic acid treatment; Sajjad et al. (2014), Padmalatha et al. (2014), Khalil (2015), Pawar et al. (2018), Tamrakar et al. (2018) and Hassan and Abd El-Azeim (2020) revealed that corms and cormels production of gladiolus were increased as a result of fertilizing plants with salicylic acid. Also, Fawzy et al. (2012), Ahmed (2013) and Abdou and Ibrahim (2015), on gladiolus, indicated that active yeast increased corm diameter and corm fresh and dry weights, number of cormels/plant and cormels fresh and dry weights, as well as $\mathrm{N}, \mathrm{P}$ and $\mathrm{K} \%$ Abdou et al. (2004), El-Sayed (2004) and ElDeeb (2016) on gladiolus plants concerning $\mathrm{N}$-fixing bacteria.

Therefore, the present study aimed to investigate the effect of compost and some stimulatory substances on corm and cormels production, as well as, some chemical composition constituents of gladiolus cv. Eurovisin.

\section{MATERIALS AND METHODS}

The current study was carried out at the Nursery of Ornamental Plants, Faculty of Agriculture, Minia University during the two successive seasons of 2017/2018 and $2018 / 2019$ to investigate the effect of compost, and some stimulatory substances, as well as, their interactions on corm and cormels production as well as some chemical composition constituents of gladiolus (Gladiolus grandiflorus, cv. Eurovision) plants.

The corms of Gladiolus grandiflorus, cv. Eurovision were obtained from Holland by Basiouny Nurseries, Cairo, Egypt. Average corm diameter was 3.0 and $3.3 \mathrm{~cm}$ and average corm weight was 9.9 and $10.4 \mathrm{~g}$ for both seasons, respectively, corms were soaked in Pinlate at $1.0 \mathrm{~g} / 1$ for one minute before planting in both seasons. The experiment was arranged in a randomized complete block design in a split plot design with three replicates. The main plot (A) included four levels of compost 0.0, 7.5, 10.0 and 12.5 ton/fed), while seven treatments of stimulatory substances occupied the sub-plot (B), namely, control, seaweeds extract (300 ppm), amino acids (200 ppm), ascorbic acid (100 ppm), salicylic acid (50 ppm), active yeast $(5 \mathrm{~g} / \mathrm{l})$ and Minia azotein $(50 \mathrm{ml} /$ plant $)$. Therefore, the interaction treatments (A x B) were 28 treatments. The experimental unit (plot) was $1.5 \times 1.8 \mathrm{~m}$ containing 3 ridges, $50 \mathrm{~cm}$ apart. Corms were planted on September $1^{\text {st }}$ for both seasons in hills, 15 $\mathrm{cm}$ apart (12 corms/ridge). The physical and chemical analyses of the used soil in both seasons were determined according to Page et al. (1982) and shown in Table (a).

Compost (plant residues) was obtained from Egypt Company for Circulate Solid Residues at El-Minia New City and added during preparing the soil to cultivation in both seasons. The chemical analysis of compost is shown in Table (b).

Minia azotein (containing $\mathrm{N}$-fixing bacteria) was obtained from the Laboratory of Bio-fertilizers, Genetic Department, Faculty of Agriculture, Minia University. It was applied at $50 \mathrm{ml} /$ plant three times to the soil around each plant, one month and two months from planting date, and after flowers cut.

The dry matter of yeast (Saccharomyces cerevisia), was $95 \%$ and live cells were 11.6 x $10^{9} / \mathrm{g}$. The yeast suspension was prepared by dissolving dry yeast and sugar together (ratio of $1: 1, \mathrm{w} / \mathrm{w}$ basic) in warm water (38 ${ }^{\circ} \mathrm{C}$ ) and let it to stand for two hours before spraying to enhance yeast activity (Skoog and Miller, 1957), chemical analysis of the dry yeast is presented in Table (c). 
Table a. Physical and chemical properties of the used soil during the two seasons of 2017/2018 and 2018/2019.

\begin{tabular}{|c|c|c|c|c|c|}
\hline \multirow{2}{*}{ Soil characte } & \multicolumn{2}{|c|}{ Values } & \multirow{2}{*}{$\begin{array}{c}\text { Soil } \\
\text { character }\end{array}$} & \multicolumn{2}{|c|}{ Values } \\
\hline & 2017/2018 & 2018/2019 & & $2017 / 2018$ & 2018/2019 \\
\hline \multicolumn{3}{|c|}{ Physical properties } & \multicolumn{3}{|c|}{ Exchangeable nutrients } \\
\hline Sand $(\%)$ & 28.98 & 28.90 & $\mathrm{Ca}^{++}(\mathrm{mg} / 100 \mathrm{~g}$ soil $)$ & 31.12 & 31.43 \\
\hline Silt (\%) & 29.87 & 30.64 & $\mathrm{Mg}^{++}(\mathrm{mg} / 100 \mathrm{~g}$ soil $)$ & 3.51 & 3.56 \\
\hline Clay (\%) & 41.15 & 40.46 & $\mathrm{Na}^{+}(\mathrm{mg} / 100 \mathrm{~g}$ soil $)$ & 2.51 & 2.50 \\
\hline Soil type & Clay loam & Clay loam & $\mathrm{K}^{+}(\mathrm{mg} / 100 \mathrm{~g}$ soil $)$ & 2.85 & 2.64 \\
\hline \multicolumn{3}{|c|}{ Chemical properties } & \multicolumn{3}{|c|}{ DTPA-Extractable nutrients } \\
\hline pH (1:2.5) & 7.75 & 7.71 & $\mathrm{Fe}(\mathrm{ppm})$ & 8.23 & 8.11 \\
\hline E.C. $(\mathrm{dS} / \mathrm{m})$ & 1.08 & 1.06 & $\mathrm{Cu}(\mathrm{ppm})$ & 2.01 & 2.00 \\
\hline O.M. & 1.54 & 1.59 & $\mathrm{Zn}(\mathrm{ppm})$ & 2.87 & 2.89 \\
\hline $\mathrm{CaCO}_{3}$ & 2.11 & 2.10 & $\mathrm{Mn}(\mathrm{ppm})$ & 8.11 & 8.15 \\
\hline
\end{tabular}

Table b. Chemical analysis of the used compost in both seasons of 2017/2018 and 2018/2019.

\begin{tabular}{lclc}
\hline Properties & Values & Properties & Values \\
\hline Organic carbon (\%) & 25.1 & Total P (\%) & 0.5 \\
Humidity (\%) & 25.0 & Total K (\%) & 1.0 \\
Organic matter & 44.0 & $\mathrm{Fe}(\mathrm{ppm})$ & 1750 \\
C/N ratio & 17.5 & $\mathrm{Zn}(\mathrm{ppm})$ & 60 \\
pH $(1: 2.5)$ & 8.0 & $\mathrm{Mn}(\mathrm{ppm})$ & 125 \\
E.C. $(\mathrm{m} . \mathrm{mhos} / \mathrm{cm})$. & 5.0 & $\mathrm{Cu}(\mathrm{ppm})$ & 200 \\
Total N (\%) & 1.5 & & \\
\hline
\end{tabular}

Table c. Chemical analysis of the used active dry yeast in both seasons of 2017/2018 and 2018/2019.

\begin{tabular}{ccccc}
\hline Protein (\%) & Ash (\%) & Glycogen (\%) & Fat (\%) & Cellulose (\%) \\
\hline 34.87 & 7.55 & 6.54 & 2.09 & 4.92 \\
\hline
\end{tabular}

Algeser product contains seaweeds extract, which was obtained from Shoura Chemical Company, Cairo-Alexandria Desert Road, Giza Governorate, Egypt. The chemical properties of the used seaweeds extract were listed in Table (d).

Aminoactal product contains a mixture of three amino acids (treptophan, methionine and cysteine), which was obtained from Shoura Chemical Company, CairoAlexandria Desert Road, Giza Governorate, Egypt.

The seaweeds extract, amino acids, ascorbic acid, salicylic acid and yeast were applied by hand spraying till run off, three times on the same schedule of Minia azotein bio-fertilizer. The agricultural practices were performed as usual in the cultivation region.

\section{The following data were recorded:}

1. Under ground parts: As flowering diminished, under ground parts were lift 2 months after cut spikes. Under ground parts characters at harvesting, after the foliage were dried, data recorded were: corms diameter $(\mathrm{cm})$, number of cormels/plant and fresh weight of cormels/plant (g).

2. Chemical analysis: determination of three photosynthetic pigments (chlorophyll $\mathrm{a}, \mathrm{b}$ and carotenoids content as $\mathrm{mg} / \mathrm{g}$ f.w.) according to Moran (1982), as well as, N, $\mathrm{P}$ and $\mathrm{K} \%$ as methods described by Wilde et al. (1985), Chapman and Pratt (1975) and Cottenie et al. (1982), respectively.

All obtained data were tabulated and statistically analyzed according to MSTATC (1986) and LSD test at 5\% was followed to compare between the means of treatments. 
Table d. Chemical properties of the used seaweeds extract in both seasons of 2017/2018 and 2018/2019.

\begin{tabular}{lclclc}
\hline \multicolumn{1}{c}{ Character } & Value & \multicolumn{1}{c}{ Character } & Value & Character & Value \\
\hline Moisture \% & 6.0 & $\mathrm{P} \%$ & $0.02-0.09$ & Zn ppm & $10-00$ \\
Organic matter \% & $45-60$ & $\mathrm{~K} \%$ & $1.0-1.2$ & $\mathrm{~B} \mathrm{ppm}$ & $20-100$ \\
Inorganic matter \% & $45-60$ & $\mathrm{Ca} \%$ & $0.2-1.5$ & Mo ppm & $1-5$ \\
Protein \% & $6-8$ & $\mathrm{~S} \mathrm{\%}$ & $3-9$ & Cytokinins \% & 0.02 \\
Carbohydrate \% & $35-50$ & $\mathrm{Mg} \%$ & $0.5-0.9$ & IAA \% & 0.03 \\
Aliginic acids \% & $10-20$ & $\mathrm{Cu} \mathrm{ppm}$ & $1.0-6.0$ & $\mathrm{ABA} \%$ & 0.01 \\
Mannitol \% & $4-7$ & $\mathrm{Fe} \mathrm{ppm}$ & $50-200$ & & \\
Total N \% & $1.0-1.5$ & $\mathrm{Mn} \mathrm{ppm}$ & $5-12$ & & \\
\hline
\end{tabular}

\section{RESULTS AND DISCUSSION}

\section{Corm and cormels productivity:}

Data presented in Table (1) showed that the corm diameter, number of cormels/plant and fresh weight of cormels/plant were significantly increased due to the fertilizing gladiolus with compost at 7.5, 10.0 and 12.5 $\mathrm{t} /$ fed compared with control. The highest values were obtained as recorded 3.75 and $3.73 \mathrm{~cm}$, and 71.8 and 73.3 cormels/plant, and 79.41 and $81.34 \mathrm{~g}$ f.w./plant in the first and second season, respectively. Similar results were investigated by Ruppenthal and Castro (2005), Ahmed (2013), Abdou and Ibrahim (2015), Beck et al. (2019), Karagöz et al. (2019) and Hassan and Abd El-Azeim (2020) on gladiolus plants.

Regarding the sub-plot treatments, using any one of the six treatments significantly increased corms diameter, number of cormels/plant and fresh weight of cormels/plant, in both seasons, as compared to control. Minia azotein treatment produced the widest corm diameter (3.35 and 3.61 $\mathrm{cm})$, highet number of cormels/plant (70.6 and 72.5 cormels/plant) and heaviest fresh weight (77.63 and $79.13 \mathrm{~g}$ f.w.) in both seasons respectively. Similar observation was pointed out by Abdou et al. (2004), Taha and Hassan (2008), Bazaraa et al. (2011), and Baruati (2018), on gladiolus plants, regarding the effect of biofertilizers, while, Ahmed (2013), Abdou and Ibrahim (2015), on gladiolus, concerning the effect of active yeast. Also, Abd El-Aziz et al. (2009), Sewedan et al. (2012) and Hashish et al. (2015), Hassan (2016) and Khattab et al. (2016) indicated that amino acids improved corm and cormels production of gladiolus, moreover, Hassan (2016), on gladiolus, found that seaweeds extract increased new corm diameter and cormels weight per plant. Meanwhile, Khalil (2015) concluded that antioxidant treatments (ascorbic and/or salicylic acid) coused enhancement of corms and cormels productivity of gladiolus plants.

The interaction between the main and sub-plots (A x B) was significant for all studied parameters of corm and cormels productivity in both seasons. The maximum values were recorded due to the interaction treatments of compost at $12.5 \mathrm{t} / \mathrm{fed}$ in combination with Minia azotein or by 12.5 $t /$ fed compost with active yeast.

Similarly, were the results Ahmed (2019) on gladiolus, regarding the best interaction between compost and amino acid, and Ahmed (2013) on gladiolus, concerning the effect of interaction between compost and active yeast.

\section{Chemical composition:}

\section{Photosynthetic pigments:}

Data presented in Table (2) indicated that supplying plants with compost at 7.5, 10.0 and $12.5 \mathrm{t} / \mathrm{fed}$ led to significant increases in photosynthetic pigments i.e. chlorophyll a, b and carotenoids, in both seasons, as compared to control. The treatment of $12.5 \mathrm{t} /$ fed compost was the most effective than the other treatments as gave $2.162 \mathrm{mg} / \mathrm{g}$ f.w chlorophyll a, $1.223 \mathrm{mg} / \mathrm{g}$ f.w chlorophyll $\mathrm{b}$ and $1.631 \mathrm{mg} / \mathrm{g}$ f.w carotenoids in the first season against control (1.025, 0.331 and 1.172 , respectively). In the second season, such superior treatment 
Table 1. Effect of compost, some stimulatory substances and their combination on corm diameter, number of cormels/plant and fresh weight of cormels/plant of gladiolus cv. Eurovisin during 2017/2018 and 2018/2019 seasons.

\begin{tabular}{|c|c|c|c|c|c|c|c|c|c|c|}
\hline \multirow{3}{*}{$\begin{array}{c}\text { Stimulatory substances } \\
\text { treatment (B) }\end{array}$} & \multicolumn{10}{|c|}{ Compost levels (ton/feddan) (A) } \\
\hline & $\mathbf{0}$ & 7.5 & 10.0 & 12.5 & $\begin{array}{c}\text { Mean } \\
\text { (B) }\end{array}$ & $\mathbf{0}$ & 7.5 & 10.0 & $12 / 5$ & $\begin{array}{c}\text { Mean } \\
\text { (B) }\end{array}$ \\
\hline & \multicolumn{5}{|c|}{ The $1^{\text {st }}$ season $(2017 / 2018)$} & \multicolumn{5}{|c|}{ The $2^{\text {nd }}$ season $(2018 / 2019)$} \\
\hline & \multicolumn{10}{|c|}{ Corms diameter (cm) } \\
\hline Control & 2.37 & 2.93 & 3.21 & 3.58 & 3.02 & 3.00 & 3.13 & 3.32 & 3.53 & 3.24 \\
\hline Seaweed extract, $300 \mathrm{ppm}$ & 2.47 & 3.17 & 3.33 & 3.73 & 3.18 & 3.18 & 3.30 & 3.50 & 3.71 & 3.42 \\
\hline Amino acids, 200 ppm & 2.57 & 3.29 & 3.40 & 3.89 & 3.29 & 3.28 & 3.42 & 3.64 & 3.87 & 3.55 \\
\hline Ascorbic acids, 100 ppm & 2.47 & 3.08 & 3.25 & 3.62 & 3.11 & 3.05 & 3.17 & 3.37 & 3.58 & 3.29 \\
\hline Salicylic acids, 100 ppm & 2.41 & 3.11 & 3.26 & 3.66 & 3.11 & 3.11 & 3.23 & 3.43 & 3.64 & 3.35 \\
\hline Active yeast, $5 \mathrm{~g} / \mathrm{l}$ & 2.52 & 3.23 & 3.40 & 3.81 & 3.24 & 3.24 & 3.37 & 3.58 & 3.80 & 3.50 \\
\hline Minia azotein, $50 \mathrm{ml}$ & 2.62 & 3.34 & 3.45 & 3.97 & 3.35 & 3.93 & 3.48 & 3.71 & 3.95 & 3.61 \\
\hline Mean (A) & 2.48 & 3.16 & 3.33 & 3.75 & 2.48 & 3.17 & 3.30 & 3.51 & 3.73 & \\
\hline \multirow[t]{2}{*}{ L.S.D. at $5 \%$} & \multicolumn{2}{|c|}{ A: 0.16} & B: 0.08 & \multicolumn{2}{|c|}{ AB: 0.16} & \multicolumn{2}{|c|}{ A: 0.19} & B: 0.11 & \multicolumn{2}{|c|}{ AB: 0.22} \\
\hline & \multicolumn{10}{|c|}{ Number of cormels/plant } \\
\hline Control & 34.1 & 38.0 & 50.2 & 54.2 & 44.2 & 34.5 & 42.1 & 53.1 & 56.3 & 46.5 \\
\hline Seaweed extract, $300 \mathrm{ppm}$ & 44.2 & 51.2 & 65.4 & 71.6 & 58.1 & 46.4 & 56.5 & 69.9 & 73.6 & 61.6 \\
\hline Amino acids, 200 ppm & 49.4 & 58.4 & 74.6 & 82.7 & 66.3 & 51.6 & 65.6 & 74.9 & 83.9 & 69.0 \\
\hline Ascorbic acids, 100 ppm & 39.1 & 44.0 & 56.3 & 60.8 & 50.1 & 40.3 & 48.3 & 59.8 & 62.5 & 52.7 \\
\hline Salicylic acids, 100 ppm & 42.1 & 48.1 & 61.4 & 66.7 & 54.6 & 44.3 & 53.4 & 65.9 & 68.5 & 58.0 \\
\hline Active yeast, $5 \mathrm{~g} / \mathrm{l}$ & 47.3 & 55.3 & 70.5 & 77.6 & 62.7 & 49.5 & 59.5 & 73.8 & 78.8 & 65.4 \\
\hline Minia azotein, $50 \mathrm{ml}$ & 51.3 & 62.5 & 79.7 & 88.8 & 70.6 & 53.6 & 66.1 & 80.5 & 89.8 & 72.5 \\
\hline Mean (A) & 43.9 & 51.1 & 66.4 & 71.8 & & 45.7 & 55.9 & 68.3 & 73.3 & \\
\hline \multirow[t]{2}{*}{ L.S.D. at $5 \%$} & \multicolumn{2}{|c|}{ A: 6.0} & B: 12.0 & \multicolumn{2}{|c|}{ AB: N.S } & \multicolumn{2}{|c|}{ A: 5.0} & B: 7.2 & \multicolumn{2}{|c|}{ AB: 14.2} \\
\hline & \multicolumn{10}{|c|}{ Fresh weight of cormels/plant (g) } \\
\hline Control & 37.51 & 41.80 & 55.22 & 59.62 & 48.54 & 38.30 & 46.73 & 59.94 & 62.47 & 51.62 \\
\hline Seaweed extract, 300 ppm & 49.06 & 56.83 & 72.59 & 79.48 & 64.47 & 51.55 & 62.77 & 77.66 & 81.77 & 68.44 \\
\hline Amino acids, 200 ppm & 54.44 & 64.33 & 82.10 & 90.90 & 72.94 & 56.77 & 72.11 & 82.40 & 92.30 & 75.90 \\
\hline Ascorbic acids, 100 ppm & 43.79 & 49.28 & 63.06 & 68.10 & 56.06 & 44.81 & 53.71 & 66.50 & 69.50 & 58.63 \\
\hline Salicylic acids, 100 ppm & 47.15 & 49.22 & 68.77 & 74.70 & 59.96 & 49.26 & 59.38 & 73.28 & 76.18 & 64.53 \\
\hline Active yeast, $5 \mathrm{~g} / \mathrm{l}$ & 52.03 & 61.38 & 77.55 & 85.36 & 69.08 & 52.03 & 65.45 & 81.92 & 87.07 & 71.72 \\
\hline Minia azotein, $50 \mathrm{ml}$ & 56.43 & 63.75 & 87.67 & 97.68 & 77.63 & 58.43 & 68.75 & 89.67 & 99.68 & 79.13 \\
\hline Mean (A) & 48.62 & 55.94 & 72.42 & 79.41 & & 50.16 & 61.27 & 75.76 & 81.34 & \\
\hline L.S.D. at $5 \%$ & A: 5 & & B: 8.45 & & 0.22 & A: 5 . & & B: 7.44 & $\mathrm{AB}$ & $: 14.88$ \\
\hline
\end{tabular}


Table 2. Effect of compost, some stimulatory substances and their combination on chlorophyll a, b and carotenoids of gladiolus cv. Eurovisin during 2017/2018 and 2018/2019 seasons.

\begin{tabular}{|c|c|c|c|c|c|c|c|c|c|c|}
\hline \multirow{3}{*}{$\begin{array}{c}\text { Stimulatory substances } \\
\text { Treatment (B) }\end{array}$} & \multicolumn{10}{|c|}{ Compost levels (ton/feddan) (A) } \\
\hline & $\mathbf{0}$ & 7.5 & 10.0 & 12.5 & $\begin{array}{c}\text { Mean } \\
\text { (B) }\end{array}$ & $\mathbf{0}$ & 7.5 & 10.0 & $12 / 5$ & $\begin{array}{l}\text { Mean } \\
\text { (B) }\end{array}$ \\
\hline & \multicolumn{5}{|c|}{ The $1^{\text {st }}$ season $(2017 / 2018)$} & \multicolumn{5}{|c|}{ The $2^{\text {nd }}$ season $(2018 / 2019)$} \\
\hline & \multicolumn{10}{|c|}{ Chlorophyll a (mg/g f.w.) } \\
\hline Control & 0.571 & 0.981 & 1.210 & 1.933 & 1.173 & 0.620 & 0.952 & 1.388 & 2.120 & 1.270 \\
\hline Seaweed extract, 300 ppm & 0.688 & 2.103 & 2.207 & 2.250 & 1.812 & 0.775 & 1.234 & 2.147 & 2.229 & 1.596 \\
\hline Amino acids, 200 ppm & 1.776 & 1.850 & 2.028 & 2.319 & 2.065 & 2.010 & 2.234 & 2.235 & 2.243 & 2.180 \\
\hline Ascorbic acids, 100 ppm & 0.493 & 0.956 & 1.435 & 2.121 & 1.251 & 0.663 & 1.159 & 1.680 & 1.737 & 1.309 \\
\hline Salicylic acids, 100 ppm & 0.754 & 1.132 & 1.281 & 2.194 & 1.340 & 1.026 & 1.055 & 1.544 & 2.207 & 1.458 \\
\hline Active yeast, $5 \mathrm{~g} / \mathrm{l}$ & 1.583 & 1.757 & 1.979 & 2.154 & 1.868 & 1.160 & 1.673 & 1.926 & 2.238 & 1.749 \\
\hline Minia azotein, $50 \mathrm{ml}$ & 1.312 & 1.360 & 2.152 & 2.166 & 1.747 & 1.267 & 1.280 & 1.643 & 1.802 & 1.498 \\
\hline Mean (A) & 1.025 & 1.448 & 1.756 & 2.162 & & 1.074 & 1.369 & 1.794 & 2.082 & \\
\hline \multirow[t]{2}{*}{ L.S.D. at $5 \%$} & \multicolumn{2}{|c|}{ A: 0.101} & B: 0.075 & \multicolumn{2}{|c|}{ AB: 0.15} & \multicolumn{2}{|c|}{ A: 0.123} & B: 0.039 & \multicolumn{2}{|c|}{ AB: N.S } \\
\hline & \multicolumn{10}{|c|}{ Chlorophyll b (mg/g f.w.) } \\
\hline Control & 0.278 & 0.433 & 0.519 & 0.904 & 0.533 & 0.309 & 0.513 & 0.732 & 0.769 & 0.580 \\
\hline Seaweed extract, 300 ppm & 0.550 & 0.574 & 1.135 & 1.138 & 0.849 & 0.517 & 0.537 & 0.720 & 1.719 & 0.873 \\
\hline Amino acids, 200 ppm & 0.336 & 1.017 & 1.301 & 1.801 & 1.113 & 0.694 & 1.532 & 1.637 & 2.014 & 1.469 \\
\hline Ascorbic acids, 100 ppm & 0.237 & 0.416 & 0.756 & 0.813 & 0.555 & 0.425 & 0.569 & 0.625 & 1,072 & 0.672 \\
\hline Salicylic acids, 100 ppm & 0.234 & 0.410 & 0.602 & 1.070 & 0.580 & 0.468 & 0.479 & 0.686 & 1.311 & 0.736 \\
\hline Active yeast, $5 \mathrm{~g} / \mathrm{l}$ & 0.338 & 0.935 & 1.213 & 1.587 & 1.018 & 0.542 & 0.700 & 0.831 & 1.778 & 0.962 \\
\hline Minia azotein, 50 ml & 0.349 & 0.475 & 0.523 & 1.251 & 0.649 & 0.355 & 0.525 & 1.109 & 1.489 & 0.869 \\
\hline Mean (A) & 0.331 & 0.608 & 0.865 & 1.223 & & 0.472 & 0.623 & 0.905 & 1.500 & \\
\hline \multirow[t]{2}{*}{ L.S.D. at $5 \%$} & \multicolumn{2}{|c|}{ A: 0.052} & B: 0.021 & \multicolumn{2}{|c|}{$1 \quad \mathrm{AB}: 0.042$} & \multicolumn{2}{|c|}{ A: 0.061} & B: 0.033 & \multicolumn{2}{|c|}{ AB: 0.066} \\
\hline & \multicolumn{10}{|c|}{ Carotenoids (mg/g f.w.) } \\
\hline Control & 0.699 & 1.331 & 1.588 & 1.589 & 1.301 & 1.171 & 1.458 & 1.546 & 1.585 & 1.440 \\
\hline Seaweed extract, 300 ppm & 1.317 & 1.541 & 1.543 & 1.585 & 1.496 & 1.488 & 1.538 & 1.539 & 1.583 & 1.537 \\
\hline Amino acids, 200 ppm & 1.552 & 1.575 & 1.585 & 1.587 & 1.574 & 1.587 & 1.587 & 1.589 & 1.589 & 1.588 \\
\hline Ascorbic acids, 100 ppm & 0.974 & 1.493 & 1.560 & 1.590 & 1.404 & 1.388 & 1.543 & 1.582 & 1.582 & 1.522 \\
\hline Salicylic acids, 100 ppm & 1.224 & 1.452 & 1.583 & 1.587 & 1.461 & 1.457 & 1.476 & 1.586 & 1.586 & 1.525 \\
\hline Active yeast, $5 \mathrm{~g} / \mathrm{l}$ & 1.238 & 1.588 & 1.589 & 1.589 & 1.510 & 1.532 & 1.573 & 1.590 & 1.590 & 1.570 \\
\hline Minia azotein, $50 \mathrm{ml}$ & 1.199 & 1.537 & 1.553 & 1.581 & 1.467 & 1.379 & 1.560 & 1.589 & 1.589 & 1.528 \\
\hline Mean (A) & 1.172 & 1.502 & 1.571 & 1.631 & & 1.428 & 1.533 & 1.572 & 1.586 & \\
\hline L.S.D. at $5 \%$ & A: 0.0 & & B: 0.088 & $\mathrm{AB}$ & 3: N.S & A: 0.0 & & B: 0.053 & & B: N.S \\
\hline
\end{tabular}


recorded $2.082 \mathrm{mg} / \mathrm{g}$ f.w. chlorophyll a, $1.500 \mathrm{mg} / \mathrm{g}$ f.w. chlorophyll $\mathrm{b}$ and 1.586 $\mathrm{mg} / \mathrm{g}$ f.w. carotenoids against $1.074,0.472$ and $1.428 \mathrm{mg} / \mathrm{g}$ f.w. respectively, for control.

These results are in agreement with those obtained by Abdou et al. (2013), Khalil (2015), Abdou et al. (2018) and Hassan and Abd El-Azeim (2020) on gladiolus plants and Mirkalae et al. (2013) on Easter lily plants.

Regarding the effect of sub plot treatments, data presented in Table (2) showed that all the used six treatments significantly increased chlorophyll a, b and carotenoids content comparing with control. Among the used six treatments, amino acids treatment overall significantly increased the three photosynthetic pigments in both seasons. Active yeast came in the second place, while, ascorbic acid gave the lowest values regardless the control. Other treatments recorded an intermediate value.

Many authors concluded that amino acids enhanced chlorophyll, such as, Abd ElAziz et al. (2009), Sewedan et al. (2012) and Hassan (2016) on gladiolus plants also, Ahmed (2013), on gladiolus, reported that the photosynthetic pigments were increased with active yeast. The stimulatory effect of biofertilizers on photosynthetic pigments was observed by El-Sayed (2004) and Hassan and Abd El-Azeim (2020). Hassan (2016), on gladiolus plants, mentioned that seaweed treatment increased photosynthetic pigments. Moreover, antioxidant treatments improved pigments of gladiolus (Sajjad et al., 2014 and Khalil, 2015, regarding salicylic acid and Khalil, 2015 and Abdou et $a l ., 2019$, concerning ascorbic acid).

The interaction was significant for chlorophyll $\mathrm{a}$ in the first season and chlorophyll $b$ in both seasons, as well as, not significant in both seasons for carotenoids. The highest values were obtained by using compost at $12.5 \mathrm{t} / \mathrm{fed}$ in combination with either amino acids or active yeast.

\section{2. $\mathrm{N}, \mathrm{P}$ and $\mathrm{K} \%$ :}

Data presented in Table (3) indicated that the percentages of $\mathrm{N}, \mathrm{P}$ and $\mathrm{K}$ were significantly increased due to fertilizing gladiolus plants with compost $(7.5,10.0$ and $12.5 \mathrm{t} / \mathrm{fed})$ in both seasons, compared to control. Compost at $12.5 \mathrm{t} /$ fed resulted the highest percentages as gave 1.921, 0.374 and1.185 in the first season and 2.030, 0.381 and 1.181 in the second one, respectively, due to $\mathrm{N}, \mathrm{P}$ and $\mathrm{K} \%$.

Similar results were obtained by Abdou et al. (2013), Khalil (2015), Hassan (2016), Abdou et al. (2018) and Hassan and Abd ElAzeim (2020) on gladiolus plants.

Regarding the effect of stimulatory substances (seaweeds extract, amino acids, ascorbic acid, salicylic acid, active yeast and Minia azotein), data presented in Table (3) showed that all the used six treatments significantly increased $\mathrm{N}, \mathrm{P}$ and $\mathrm{K} \%$ in the dry leaves in both seasons comparing with control. Minia azotein treatment was the most effective than the other used treatments in this concern.

Many authors evaluated the effect of biofertilizer such as, El-Sayed (2004), Taha and Hassan (2008), Abdou and Ibrahim (2015), Mazhar and Eid (2016), Sathyanarayana et al. (2018) and Hassan and Abd El- Azeim (2020) on gladiolus and Attia et al., (2018) on tuberose plants.

Hassan (2016) on gladiolus and Afifpour and Kosh-Khui (2015) on Polianthes tuberosa found that amino acids have positive effect on $\mathrm{N}, \mathrm{P}$ and $\mathrm{K} \%$. Moreover, Ahmed (2013) on gladiolus mentioned that active yeast increased $\mathrm{N}, \mathrm{P}$ and $\mathrm{K} \%$. However, Sajjed et al. (2014), Khalil (2015), Abdou et al. (2018) concluded that salicylic acid increased $\mathrm{N}, \mathrm{P}$ and $\mathrm{K} \%$, while Khalil (2015), Abdou and Ibrahim (2015) and Abdou et al. (2019) on gladiolus concluded that ascorbic acid have positive effects on $\mathrm{N}$, $\mathrm{P}$ and $\mathrm{K} \%$.

The interaction was significant for $\mathrm{N}$ and $\mathrm{P} \%$ in both seasons. The best interaction 
Table 3. Effect of compost, some stimulatory substances and their combination on nitrogen, phosphorus and potassium percentages of gladiolus cv. Eurovisin during 2017/2018 and 2018/2019 seasons.

\begin{tabular}{|c|c|c|c|c|c|c|c|c|c|c|}
\hline \multirow{3}{*}{$\begin{array}{c}\text { Stimulatory substances } \\
\text { Treatment (B) }\end{array}$} & \multicolumn{10}{|c|}{ Compost levels (ton/feddan) (A) } \\
\hline & $\mathbf{0}$ & 7.5 & 10.0 & 12.5 & $\begin{array}{l}\text { Mean } \\
\text { (B) }\end{array}$ & $\mathbf{0}$ & 7.5 & 10.0 & $12 / 5$ & $\begin{array}{c}\text { Mean } \\
\text { (B) }\end{array}$ \\
\hline & \multicolumn{5}{|c|}{ The $1^{\text {st }}$ season $(2017 / 2018)$} & \multicolumn{5}{|c|}{ The $2^{\text {nd }}$ season $(2018 / 2019)$} \\
\hline & \multicolumn{10}{|c|}{ Nitrogen (\%) } \\
\hline Control & 1.531 & 1.622 & 1.755 & 1.841 & 1.687 & 1.552 & 1.643 & 1.776 & 1.863 & 1.709 \\
\hline Seaweed extract, $300 \mathrm{ppm}$ & 1.651 & 1.746 & 1.875 & 1.960 & 1.808 & 1.700 & 1.795 & 1.925 & 2.011 & 1.858 \\
\hline Amino acids, 200 ppm & 1.762 & 1.856 & 1.986 & 2.072 & 1.920 & 1.833 & 1.926 & 2.056 & 2.145 & 1.990 \\
\hline Ascorbic acids, 100 ppm & 1.582 & 1.675 & 1.806 & 1.890 & 1.738 & 1.612 & 1.706 & 1.835 & 1.920 & 1.768 \\
\hline Salicylic acids, 100 ppm & 1.611 & 1.706 & 1.835 & 1.920 & 1.768 & 1.651 & 1.745 & 1.876 & 1.961 & 1.808 \\
\hline Active yeast, $5 \mathrm{~g} / \mathrm{l}$ & 1.708 & 1.795 & 1.925 & 2.011 & 1.858 & 1.763 & 1.855 & 1.985 & 2.072 & 1.919 \\
\hline Minia azotein, $50 \mathrm{ml}$ & 1.843 & 1.937 & 2.068 & 2.155 & 2.001 & 1.923 & 2.018 & 2.148 & 2.236 & 2.081 \\
\hline Mean (A) & 1.669 & 1.762 & 1.893 & 1.921 & & 1.719 & 1.813 & 1.943 & 2.030 & \\
\hline \multirow{2}{*}{ L.S.D. at $5 \%$} & A: 0 . & & B: 0.041 & $\mathrm{AB}:$ & $: 0.082$ & A: 0.0 & & B: 0.044 & $\mathrm{AB}$ & 0.088 \\
\hline & \multicolumn{10}{|c|}{ Phosphorus (\%) } \\
\hline Control & 0.211 & 0.243 & 0.274 & 0.302 & 0.258 & 0.222 & 0.256 & 0.285 & 0.313 & 0.269 \\
\hline Seaweed extract, 300 ppm & 0.293 & 0.324 & 0.355 & 0.380 & 0.338 & 0.300 & 0.331 & 0.360 & 0.393 & 0.346 \\
\hline Amino acids, 200 ppm & 0.312 & 0.341 & 0.376 & 0.410 & 0.360 & 0.315 & 0.352 & 0.382 & 0.411 & 0.365 \\
\hline Ascorbic acids, 100 ppm & 0.251 & 0.283 & 0.311 & 0.341 & 0.298 & 0.260 & 0.291 & 0.322 & 0.351 & 0.306 \\
\hline Salicylic acids, 100 ppm & 0.272 & 0.301 & 0.332 & 0.361 & 0.317 & 0.281 & 0.311 & 0.341 & 0.372 & 0.326 \\
\hline Active yeast, $5 \mathrm{~g} / \mathrm{l}$ & 0.301 & 0.331 & 0.365 & 0.400 & 0.349 & 0.310 & 0.341 & 0.371 & 0.401 & 0.356 \\
\hline Minia azotein, $50 \mathrm{ml}$ & 0.325 & 0.353 & 0.387 & 0.426 & 0.373 & 0.324 & 0.361 & 0.395 & 0.427 & 0.377 \\
\hline Mean (A) & 0.281 & 0.311 & 0.343 & 0.374 & & 0.287 & 0.320 & 0.351 & 0.381 & \\
\hline \multirow[t]{2}{*}{ L.S.D. at $5 \%$} & \multicolumn{2}{|c|}{ A: 0.011} & B: 0.009 & AB: & $: 0.018$ & A: 0.0 & & B: 0.010 & $\mathrm{AB}$ & 0.020 \\
\hline & \multicolumn{10}{|c|}{ Potassium (\%) } \\
\hline Control & 1.111 & 1.123 & 1.132 & 1.138 & 1.126 & 1.117 & 1.126 & 1.135 & 1.140 & 1.130 \\
\hline Seaweed extract, 300 ppm & 1.147 & 1.169 & 1.179 & 1.181 & 1.169 & 1.143 & 1.160 & 1.171 & 1.177 & 1.163 \\
\hline Amino acids, 200 ppm & 1.166 & 1.189 & 1.196 & 1.201 & 1.188 & 1.165 & 1.183 & 1.195 & 1.199 & 1.186 \\
\hline Ascorbic acids, 100 ppm & 1.136 & 1.154 & 1.164 & 1.166 & 1.155 & 1.139 & 1.156 & 1.168 & 1.178 & 1.160 \\
\hline Salicylic acids, 100 ppm & 1.125 & 1.143 & 1.153 & 1.155 & 1.144 & 1.128 & 1.145 & 1.156 & 1.162 & 1.148 \\
\hline Active yeast, $5 \mathrm{~g} / \mathrm{l}$ & 1.155 & 1.178 & 1.185 & 1.190 & 1.177 & 1.154 & 1.170 & 1.182 & 1.189 & 1.174 \\
\hline Minia azotein, $50 \mathrm{ml}$ & 1.169 & 1.199 & 1.210 & 1.221 & 1.200 & 1.174 & 1.194 & 1.215 & 1.229 & 1.201 \\
\hline Mean (A) & 1.144 & 1.165 & 1.174 & 1.185 & & 1.146 & 1.162 & 1.175 & 1.181 & \\
\hline L.S.D. at $5 \%$ & A: 0. & 011 & B: 0.008 & & 3: N.S & A: 0.0 & & B: 0.009 & $\mathrm{AB}$ & 3: N.S \\
\hline
\end{tabular}


treatment was 12.5 ton/fed compost in combination with Minia azotein.

\section{CONCLUSION}

It could be recommended from our results that to obtain the best production of gladiolus corm and cormels characters, it should be fertilized with compost at 12.5 ton/fed and inoculation the soil of gladiolus with Minia azotein (50 ml/plant) or spraying plants with amino acids (200 ppm).

\section{REFERENCES}

Abd El-Aziz, N.G.; Taha, L.S. and Ibrahim, S.M.M. (2009). Some studies on the effect of putrescine, ascorbic acid and thiamine on growth, flowering and some chemical constituents of Gladiolus plants at Nubaria. Ozean J. of Applied Sci., 2(2):169-179.

Abdou, M.A.H. and Ibrahim, T.I.E. (2015). Response of gladiolus cv. Carmen to compost, biofertilization and some vitamin treatments. Proc. the 1st Conf. of SSFOP "Future of Ornamental Plants in Egypt", Cairo, Egypt, Scientific J. Flowers \& Ornamental Plants, 2(1):1-10.

Abdou, M.A.H.; Aly, M.K. and Ahmed, A.S.A. (2013). Effect of compost, biofertilization and some vitamins addition on Gladiolus grandiflorus J. Plant Production, Mansoura Univ., 4(12):1751-1761.

Abdou, M.A.H.; Aly, M.K.; El-Sayed, A.A. and Ahmed, A.S.A. (2019). Influence of organic, mineral, biofertilizers and some vitamin treatments on: A. Vegetative growth and flowering aspects of Gladiolus grandiflorus var. Gold Field plants. Scientific J. Flowers \& Ornamental Plants, 6(2):113-124.

Abdou, M.A.H.; Attia, F.; Aly, M.K. and Sayed, I.H. (2004). Response of gladiolus plants to some bio and chemical fertilization treatments. 1- Vegetative growth and flowering; Proc. The Fifth Arabian Hort. Conf. Ismailia, Egypt, 2428 March, 1:50-62.
Abdou, M.A.H.; Badran, F.S.; Ahmed, E.T.; Taha, R.A. and Abdel-Mola, M.A.M. (2018). Effect of compost and some natural stimulant treatments on: I. Vegetative growth and flowering aspects of Gladiolus grandiflorus cv. Peter Pears plants. Proc. the $4^{\text {th }}$ Conf. of SSFOP "Ornamental Plants and Environment", Cairo, Egypt, Scientific J. Flowers \& Ornamental Plants, 5(2):105-114.

Abo Leila, B. and Eid, R. (2011). Improving gladiolus growth, flower keeping quality by using some vitamins application. Journal of American Science, 7(3):169174.

Afifipour, Z. and Kosh-Khui, M. (2015). Efficacy of spraying a mixture of amino acids on the physiological and morphological characteristics of tuberose (Polianthes tuberosa L.). International J. of Hort. Sci., 2(2):199-204.

Ahmed, A.S.A. (2013). Physiological Studies on Gladiolus Plant. M.Sc. Thesis, Fac. Agric., Minia Univ., Egypt, 188 p.

Ahmed, A.S.A. (2019). Exogenous application of calcium improved the vegetative attributes and corm production in gladiolus. Sarhad Journal of Agriculture, 35(3):1011-1019.

Attia, K.E.; Elbohy, N.F.S. and Ashour, N.A.M. (2018). Response of tuberose plants (Polianthes tuberosa. L.) to chemical and bio fertilization and their effect on vegetative growth, flowering and chemical composition under sandy soil conditions. Scientific J. Flowers \& Ornamental Plants, 5(3):261-273.

Baruati, D.; Talukdar, M.C. and Kumar, V. (2018). Effect of organic manures and biofertilizers on growth and yield of gladiolus (Gladiolus grandiflorus, L.). International Journal of Chemical Studies, 6(5):2529-2532.

Bazaraa, W.M.; Said, R.M. and Nabih, A. (2014). Effect of growing media, bio and chemical fertilization on the production of gladiolus (cv. Novalux) corms from 
cormlets. Scientific J. Flowers \& Ornamental Plants, 1(1):89-100.

Beck, S.K.; Beck, M.K. and Agrawa, P. (2019). Analyzing different spacing and fertilizer applications interaction effect on growth, flowering and yield of gladiolus (Gladiolus grandiflorus, L.). Int. J. Curr. Microbiol. App. Sci., 8(4): 707-715.

Champan, H.D. and Pratt, P.F. (1975). Methods of Analysis for Soil, Plant and Water. Calif. Univ. Division of Agric. Sci., 172-174.

Chandar, I.; Rawat, I.; Lakhawat, S.S. and Yadav, K.K. (2012). Effect of organic manures and biofertilizers on the yield parameters of Gladiolus cv. White Prosperity. Ecol., Environ. and Conservation Paper, 18(1):91-94.

Cottenie, A.; Verloo, M.; Velghe, M. and Camerlynck, R. (1982). Chemical Analysis of Plant and Soil. Laboratory of Analytical and Agro Chemistry, State Univ., Ghent, Belgium, p. 44-45.

El-Deeb, M.B.E.M. (2016). Effect of Mineral and Bio-Fertilization on the Vegetative Growth, Flowering and Corms Production of Gladiolus Plant Growing Under Different Media. Ph.D. Thesis, Fac. Agric., Alex Univ., 165 p.

El-Sayed, E.H. (2004). Response of Gladiolus Plants to Some Bio and Chemical Fertilization Treatments. Ph.D. Thesis, Fac. Agric., Minia Univ., Egypt, $142 \mathrm{p}$.

Fawzy, Z.F.; Abou El-Magd, M.M.; Yunsheng, L.; Ouyang, Z. and Hoda, A.M. (2012). Influence of foliar application by EM (effective microorganisms), amino acids and yeast on growth, yield and quality of two cultivars of onion plants under newly reclaimed soil. J. of Agri. Sci., 4(11): 2639.

Hashish, Kh.L.; Eid, R.A.; Kandil, M.M. and Mazhar, A.A.M. (2015). Study on various levels of salinity on some morphological and chemical composition of gladiolus plants by foliar spray with glutathione and thiamine. International J. of Chem. Tech. Res., 9(8):334-341.

Hassan, A.A. (2016). Response of Gladiolus Plant to Some Fertilization and Antioxidant Treatments. Ph.D. Thesis, Fac. Agric., Minia Univ., Egypt, 215 p.

Hassan, A.A. and Abd El-Azeim, M.M. (2020). Impacts of compost, biofertilizer and/or some antioxidant treatments on gladiolus (Gladiolus grandifloras), A. Vegetative growth and flowering aspects. Scientific J. Flowers \& Ornamental plants, 7(3):269-283.

Karagöz, F.P.; Dursun, A.; Tekiner, N.; Kul, R. and Kotan, R. (2019). Efficacy of vermicompost and/or plant growth promoting bacteria on the plant growth and development in gladiolus. Ornamental Horticulture Journal, 25(2):180-188.

Khalil, A.R.M. (2015). Physiological Studies on Gladiolus Plant. M.Sc. Thesis, Fac. Agric., Minia Univ., Egypt, 146 p.

Khattab, M.; Shehata, A.; El-Saadate, E.A. and El-Hasni, K. (2016). Effect of glycine, methionine and tryptophan on vegetative growth, flowering and corms production of Gladiolus plant. Alex. Sci. Exch. J., 37:647-659.

Mazhar, A.A.M. and Eid, R.A. (2016). Effect of various doses of chemical fertilizer (kristalon) individually or in combination with different rates of biofertilizer on growth, flowering, corms yield and chemical constituents of Gladiolus grandiflorus. Internat ional Journal of Pharm Tech Research, 9(12): 139-145.

Mirkalae, S.M.; Ardebili, Z.O. and Mostafavi, M. (2013). The effects of different organic fertilization on the growth of Lilium longiflorum. Inter. Res. J. of Applied and Basic Sci., 4(1):181186. 
Moran, R. (1982). Formula determination of chlorophylls pigments extracted with $\mathrm{N}$ dimethyl formamide. Plant Physiology, 69: 1376-1381.

MSTAT-C (1986). A Microcomputer Program for The Design Management and Analysis of Agronomic Research Experiments (version 4.0), Michigan State Univ., U.S.A.

Padmalatha, T.; Reddy, G.S.; Chandrasekhar, R.; Siva shankar, A. and Chaturvedi, A. (2014). Effect of preplanting soaking of corms with chemicals and plant growth regulators on dormancy breaking and corm and cormel production in Gladiolus. IJPAES, 3(1):29-33.

Page, A.L.; Miller, R.H. and Keeney, D.R. (1982). Methods of Soil Analysis; 2. Chemical and Microbiological Properties, American Soc. of Agronomy, Madison, Wisconsin, USA, 1159 p.

Pawar, A.; Chopde, N. and Nikam, B. (2018). Thiourea and salicylic acid influences growth, yield and quality of gladiolus. Journal of Pharmacognosy and Phytochemistry, 7(5):970-972.

Ruppenthal, V. and Castro, A.M.C. (2005). Effect of urban waste compost on nutrition and yield of Gladiolus R. Bras. Ci. Solo., 29: 145-150.

Sajjad, Y.; Jaskani, M.; Ashraf, M.; Qasim, M. and Ahmad, R. (2014). Response of morphological and physiological growth attributes to foliar application of plant growth regulators in Gladiolus "White Prosperity". Pak. J. Agric. Sci., 51(1):123-129.
Sathyanarayana, E.; Patil, S.; Bahubali, M. and Chawla, S.L. (2018). Effect of INM on gladiolus (Gladiolus grandiflorus, L.) cv. American Beauty under Navsari and Tansa Conditions. Int. J. Pure App. Biosci., 6(4):48-55.

Sewedan, E.; El-Naggar, H. and Osman, A. (2012). Effect of nitrogen and diphenylamine on Gladiolus hybrid cv. Sancerre production. J. of Hort. Sci. and Ornamental Plants, 4(3):267-274.

Skoog, F. and Miller, C. (1957). Biological Action of Growth Substances. Cambridge Univ. Press, USA, 344 p.

Taha, R.A. and Hassan, A.H. (2008). Response of gladiolus plants to mineral biofertilization and biofertilization treatments 2- Corm production and chemical constituents. Alex. J. Agric. Res., 53: 87-95.

Tamrakar, S.K.; Singh, P.; Kumar, V. and Tirkey, T. (2018). Effect of gibberellic acid, salicylic acid, cow urine and vermiwash on corm production of Gladiolus cv. Candyman. Int. J. Curr. Microbiol. App. Sci., 6:677-686.

Tirkey, P.; Kullur, L.R. and Prasad, V.M. (2017). Effect of organic and Inorganic source of N.P.K on growth and yield parameters of gladiolus (Gladiolus grandiflorus) cv. Jester. Journal of Pharmacognosy and Phytochemistry, 6(5):1004-1006.

Wilde, S.A.; Covey, R.P.; Lyer, J.C. and Voigt, G.K. (1985). Soil and Plant Analysis for Tree Culture. Oxford, IBH. Publishing Co., New Delhi, India, 224 p. 


\section{M.A.H. Abdou et al.}

\section{تأثير الكمبوست وبعض المواد المنشطة على نبات الجلاديولس \\ ب. إنتاجية الكورمات والكريمات وبعض المكونات الكيماوية}

محمود عبد الهادي حسن عبده، محمد كمال عبد العال علي، أحمد عبدالمنعم السيد، أمبرة رجائي خليل،

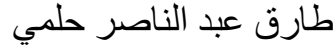

قسم البساتين، كلية الزر اعة، جامعة المنيا، مصر

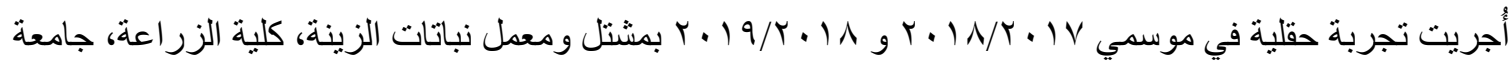

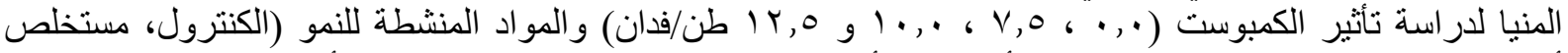

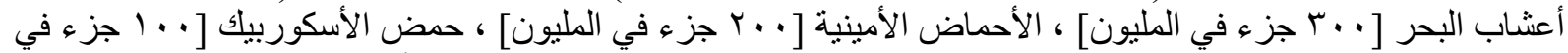

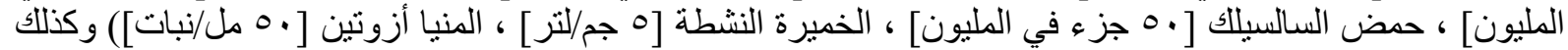

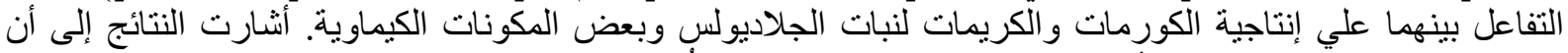

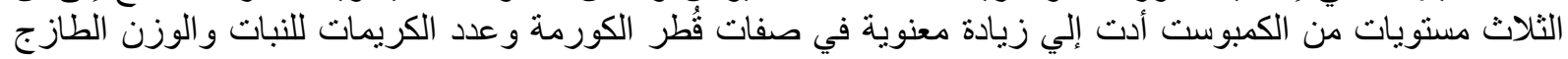

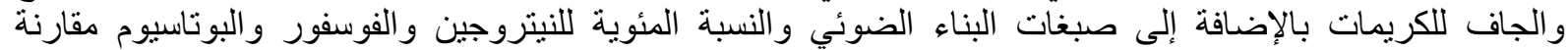

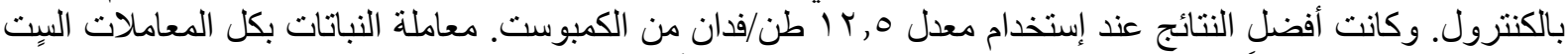

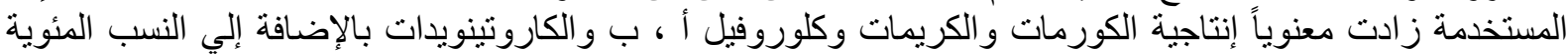

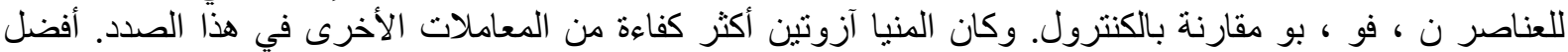

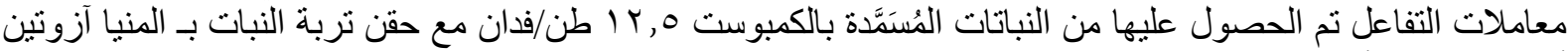
أو مع رشها بالأحماض الامينية. 